\title{
KONTRIBUSI E-WOM TERHADAP PERILAKU KONSUMTIF
}

\section{Herlina Yustati}

\section{IAIN Bengkulu}

\author{
herlina.yustati@iainbengkulu.ac.id
}

\begin{abstract}
This article starts from Laila Hifziati's research stating that in addition to being the most up-to-date promotional tool, eWOM culinary on Instagram has formed a consumptive culture. Starting from this study, this study aims to determine how much eWOM contributes through the shopee platform (Shopee platform dominates mobile applications and ranks first as the most popular shopping application on the Android and IOS platforms) on the consumptive behavior of Bengkulu IAIN students. Before knowing the size of the contribution, the results of the study show that e-Wom has a positive effect on consumptive behavior, that is, the more frequent e-Wom is used in Shopee applications, the more consumptive behavior will be. While the amount of eWom's contribution to consumptive behavior is $42.7 \%$, while $57.3 \%$ is influenced by other factors.
\end{abstract}

Kata Kunci: E-WOM, Consumptive Behavior, Students

\section{A. PENDAHULUAN}

Internet telah mengubah cara seseorang untuk mengumpulkan informasi, memberikan informasi, berkomunikasi dengan orang lain dan termasuk membantu konsumen bertukar informasi tentang produk secara online. Penetrasi pengguna internet di Indonesia meningkat menjadi 143,26 Juta jiwa setara 54,7 persen dari total populasi masyarakat Indonesia. Pada tahun 2016 jumlah pengguna internet di Indonesia mencapai 132,7 juta jiwa. ${ }^{1}$

\footnotetext{
1،BULETINAPJIIEDISI22Maret2018.Pd f," n.d
}

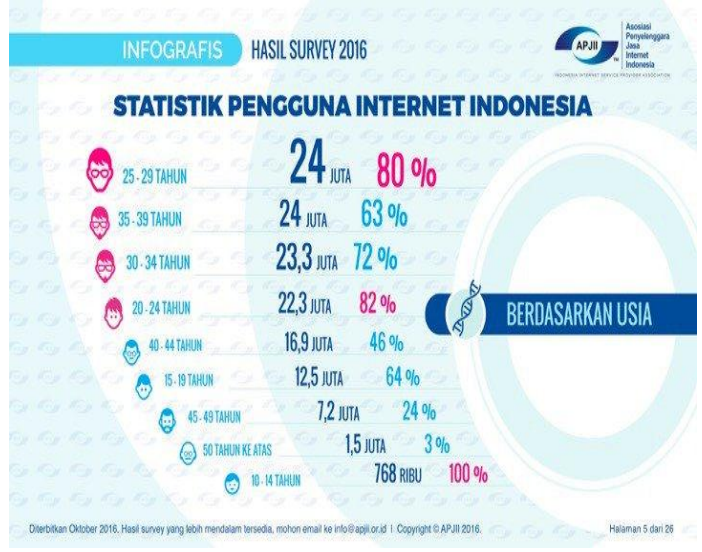

Menurut riset yang dilakukan oleh Asosiasi Penyelenggara Jasa Internet Indonesia (APJII), sebanyak $80 \%$ pengguna internet secara umum adalah anak muda yang berusia 25-29 tahun dan 64\% yang berusia 15-19 tahun. Dan sebanyak $89 \%$ pengguna internet berasal dari mahasiswa.Aksesibilitas informasi 
bisa dibilang sebagai salah satu cara terpenting sehingga Internet bisa mengubah cara belanja tradisional (bertatap muka langsung) menjadi berbelanja online.Berkembangnya internet telah membuat dunia pemasaran juga semakin berkembang. Sebagai bagian dari aktivitas bisnis e-commerce, jualbeli online semakin marak dilakukan. Tidak perlu keluar rumah dan menghadapi panasnya jalanan, ramainya pasar, antri yang panjang jika ingin membeli suatu komoditas. Dengan bermodalkan internet dan gadget transaksi jual beli menjadi sangat mudah.

Pertumbuhan e-commerce di Indonesia semakin pesat sepanjang tahun 2017. Berdasarkan riset Google Temasek beberapa laman e-commerce jadi yang paling banyak dicari oleh warganet. ${ }^{2}$ Berdasarkan riset terbaru dari Google Temasek, di tahun 2017 penjualan e-commerce akan mencapai USD 10,9 miliar. Jumlah ini meroket $41 \%$ dari angka USD 5,5 miliar yang dicapai pada tahun 2015.Laporan Google juga menyebutkan bahwa ketertarikan konsumen terhadap e-commerce tumbuh pesat di Asia Tenggara. Ini berdasarkan jumlah search volume dari nama-nama e-

${ }^{2}$ Mustiana Lestari, "E-Commerce Ini Paling Banyak Dicari Netizen Di Google," 2018, https://inet.detik.com/business/d-3847985/ecommerce-ini-paling-banyak-dicari-netizen-digoogle. commerce yang meningkat lebih dari dua kali lipat dalam 2 tahun di Google Search. $^{3}$

Konsultan analisis data dan digital, ilmuOne Data merilis studi tentang posisi dan pertumbuhan $e$ -

Commerce dan marketplace barang

konsumsi di Indonesia selama semester I 2017. Dalam studi itu mengungkapkan daftar

10 Commerce dan marketplace terbaik di Indonesia. $^{4}$

\section{Top Performing Online Consumer Goods Retailers in Indonesia}

\begin{tabular}{|c|c|c|c|c|c|c|c|}
\hline & & $\begin{array}{c}\text { Total Difitital } \\
\text { Population(000) }\end{array}$ & Mobile $(000)$ & Deskiop (000) & $\begin{array}{l}\text { Total Minutes } \\
\text { (MM) }\end{array}$ & Total Views (MM) ${ }^{\text {Avg }}$ & $\begin{array}{l}\text { Avg. Minutesper } \\
\text { View }\end{array}$ \\
\hline 1 & lazda.coid & 21,235 & 15,864 & 8,107 & 526 & 552 & 1 \\
\hline 2 & Biblicicom & 15,556 & 13,837 & 2,551 & 635 & 422 & 1.5 \\
\hline 3 & Tokopediacom & 14,401 & 13,006 & 2,217 & 1,548 & 326 & 4.7 \\
\hline 4 & Eleveniaco.id & 12,872 & 9,535 & 5,130 & 438 & 285 & 1.5 \\
\hline 5 & MatahariMall.com & 12,520 & 11,516 & 1,879 & 410 & 516 & 0.8 \\
\hline 6 & Shopee.co.id & 11,301 & 10,872 & 763 & 2,169 & 136 & 16 \\
\hline 7 & Bukalapat.com & 10,407 & 8,971 & 2,203 & 459 & 193 & 2.4 \\
\hline 8 & Zaloraccoid & 9,052 & 8,636 & 813 & 396 & 493 & 0.8 \\
\hline 9 & Qoo10.coid & 7,689 & 7,641 & 123 & 76 & 91 & 0.8 \\
\hline 10 & Blanja.com & 5,823 & 5,673 & 327 & 81 & 88 & 0.9 \\
\hline
\end{tabular}

Berdasarkan table di atas diketahui bahwa lazada merupakan flatporm belanja online nomor satu di Indonesia. Sedangkan platform Shopee mendominasi

\footnotetext{
3"Persaingan E-Commerce Indonesia Di 2017, Siapa Terpopuler?," 31 Desember, last modified 2017, accessed February 8, 2018, https://inet.detik.com/cyberlife/d-

3793019/persaingan-e-commerce-indonesia-di2017-siapa-terpopuler.

${ }^{4}$ Andina Librianty, "Ini 10 Toko Online Terbaik Di Indonesia," last modified 2017, accessed February 8, 2018, https://www.liputan6.com/tekno/read/3068210/ini10-toko-online-terbaik-di-indonesia.
} 
aplikasi mobile dan menempati ranking pertama sebagai aplikasi shopping terpopuler di platform Android dan IOS. ${ }^{5}$ Produk Online pada platform belanja online yang paling banyak diminati di Indonesia pada tahun 2016 adalah baju dan benda-benda terkait fashion, dengan metode pembayaran paling banyak adalah melalui transfer bank. ${ }^{6}$ Telepon selular digunakan oleh mayoritas pengguna Internet di Indonesia untuk mengakses web di tahun 2014, dan merupakan perangkat yang digunakan sebagian besar pembeli online untuk melakukan pembelian. ${ }^{7}$

Melalui aplikasi mobile shopping konsumen menuliskan opini, komentar bahkan review mereka tentang suatu produk pada forum diskusi dengan tujuan untuk membangun kesadaran, meningkatkan minat dan ketertarikan konsumen terhadap suatu produk ataupun merek yang pada akhirnya akan membuat konsumen melakukan tindakan pembelian terhadap produk tersebut. Kecenderungan konsumen untuk percaya terhadap review

\footnotetext{
5"Laporan Kuartal I 2018 Industri ECommerce Indonesia," last modified 2018, accessed April 20, 2018, https://iprice.co.id/trend/insights/laporan-kuartal-i2018-industri-e-commerce-indonesia/.

${ }^{6}$ Siti Nur Azzura, "Survei: Indonesia Jadi Surga Belanja Online Terbesar Se-Asia Tenggara," last modified 2017, accessed February 8, 2018, https://www.merdeka.com/uang/surveiindonesia-jadi-surga-belanja-online-terbesar-seasia-tenggara.html. ${ }^{7}$ Ibid.
}

ini lebih tinggi karena asal kepercayaanya datang dari orang yang tidak mendapatkan keuntungan dari rekomendasi pemilik barang melainkan datang dari pengguna barang (sesama konsumen).

Bagi penulis opini, pesan yang diberikan tidak memiliki maksud komersil yang kuat. Sehingga kepercayaan konsumen meningkat. Dengan adanya internet tercipta sebuah paradigma baru dalam komunikasi word of mouth dan ini adalah awal munculnya istilah electronic Word-of-Mouth atau $e$-WOM.

Ulasan online (eWOM) telah terbukti sangat penting terhadap pengambilan keputusan konsumen (Bickart dan Schindler, 2001). Konsumen beralih ke ulasan online untuk membantu dalam keputusan membeli terhadap hampir semua produk atau layanan yang tersedia untuk dibeli. Mulai dari memutuskan tempat makan, tempat bepergian atau menginap, hingga pilihan tukang kayu atau pelukis. Survei Fan and Fuel (2016) dari Desember tahun lalu menunjukkan bahwa 97\% konsumen menerapkan ulasan konsumen dalam keputusan pembelian mereka dan $92 \%$ ragu-ragu untuk melakukan pembelian jika tidak ada ulasan konsumen yang tersedia. Selain itu, Survei Tinjauan Pelanggan Lokal tahun 2017 menunjukkan bahwa 85\% konsumen percaya ulasan online sebanyak keluarga 
dan teman (BrightLocal, 2017). Ini menekankan pentingnya ulasan online. ${ }^{8}$

Elektornik Word Of Mouth memiliki pengaruh terhadap perilaku konsumen. EWom berpengaruh terhadap purchase intention, minat beli, impulse buying dan lain-lain. Dengan adanya impulse buying pada konsumen maka akan meimbulkan perilaku konsumtif pada konsumen karena keinginan berbelanja tidak lagi merupakan kebutuhan tapi karena keinginan yang tiba-tiba. Sebagaimana penelitian Laila Hifziati yang menyatakan bahwa Selain menjadi alat promosi paling mutakhir eWOM kuliner di Instagram telah membentuk sebuah kultur konsumtif. ${ }^{9}$ Dengan adanya e-Wom juga menyebabkan seseorang yang tadinya hanya ingin melihat-lihat produk pada paltform berbelanja pada akhirnya akan memutuskan membeli produk yang niat awalnya hanya untuk dilihat.

Fenomena ini ternyata tidak hanya terjadi di level masyarakat umum, tetapi juga terjadi pada mahasiswa. Di era milenial saat ini, mahasiswa tidak hanya dikenal sebagai agen perubahan di masyarakat, tetapi juga sebagai follower tren yang terjadi di masyarakat. Berbagai

\footnotetext{
${ }^{8}$ Ingrid Rabben et al., "Electronic Wordof-Mouth and Consumers 'Intention to Reviews" (2017). h. 9

${ }^{9}$ Laila Hifziati, "Pembentukan Kultur Konsumtif Melalui E-Wom Kuliner Di Instagram," Komunikator 9 No. 2 De (2017).
}

tren di masyarakat yang terus berkembang, mulai dari tren ekonomi, sosial, politik, teknologi,hingga busana dan kecantikan, tidak luput dari perhatian mahasiswa. ${ }^{10}$ Mahasiswa sebagai bagian dari kalangan remaja, dianggap sebagai pembeli potensial terutama untuk produkproduk fashion. Hal ini juga terjadi pada mahasiswa Fakultas Ekonomi dan Bisnis Islam IAIN Bengkulu, yang dalam keseharian terlihat fashionable dalam berpenampilan. Sebagai mahasiswa muslim seharusnya mampu membedakan mana keinginan dan kebutuhan. Ketika berbelanja kebutuhan fashion bukan karena kebutuhan namun sudah karena keinginan maka hal ini bisa dikategorikan sebagai perilaku konsumtif.

Berdasarkan latar belakang inilah penulis tertarik untuk meneliti bagaimana pengaruh e-wom terhadap perilaku konsumtif pada mahasiswa dan seberapa besar kontribusi $e$-wom terhadap perilaku konsumtif pada mahasiswa? Platform yang digunakan untuk melihat e-wom adalah platform Shopee karena platform Shopee mendominasi aplikasi mobile dan

\footnotetext{
${ }^{10}$ Ayu Kusumaningrum, Bagus Wicaksono, and Rahmah Saniatuzzulfa, "Hubungan Electronic Word of Mouth Dan Hedonic Shopping Motivation Dengan Perilaku Konsumtif Produk Make Up Pada Mahasiswi Relationship between Electronic Word of Mouth and Hedonic Shopping Motivation with Consumable Behavior of Make Up Products for Studen" 14 (2018).
} 
menempati ranking pertama sebagai aplikasi shopping terpopuler di platform Android dan IOS. Mayoritas mahasiswa menggunakan handphone berbasis android dan IOS sehingga sangat memungkinkan bagi mahasiswa untuk memiliki platform tersebut di Handphone yang dimiliki.

\section{B. KAJIAN TEORI}

\section{E-WOM}

Electronic word of mouth menurut Sotiriadis dalam Meuthia adalah sesuatu yang dirancang sebagai saluran komunikasi antar dua orang atau lebih melaluibmedia elektronik dalam bentuk tatap muka atau berbagi informasi via telepon, surat atau email, dan internet chat. ${ }^{11}$ MenurutThurau, dkk dalam Fungkiya Sari mengungkapkaneWOM merupakanbentuk

komunikasipemasaranyang berisitentang pernyataanpositifataunegatifyang

dilakukan konsumen potensial,maupun mantan konsumen tentang suatuproduk,yang tersediabagiorang banyak melalui mediasosial internet. ${ }^{12}$ Jadi dapat disimpulkan bahwa E-Wom adalah bentuk komunikasi melalui media

\footnotetext{
${ }^{11}$ Meuthia, "Efektifitas Electronic Word of Mouth (e-WOM) Melalui Media Sosial," Teknosi Vol. 03, no. 01 (2017): 101-108. h. 102.

${ }^{12}$ Edriana Sari, Fungki dan Pangesti, "Pengaruh Electronic Word Of Mouth (e-WOM) Terhadap Minat Berkunjung Dan Keputusan Berkunjung," Jurnal Administrasi Bisnis Vol. 54, no. 1 (2018): 189-196. h. 191.
}

elektronik yang berisi pernyataan positif atau negative tentang komoditas dan jasa dengan tujuan untuk mempengaruhi konsumen lainnya untuk melakukan pembelian.

Indikator yang digunakan dalam penelitian ini adalah indicator menurut Goyette and Richard yang membagi ewom ke dalam tiga dimensi sebagai berikut:

a. Intensity.

Intensitas disini adalah banyaknya konsumen membaca E-WOm dalam E-Commerce.

b. Valence of Opinion.

Adalah pendapat konsumen baik positif atau negatif mengenai produkbarang dan jasa.Valence of Opinion memiliki dua sifat yaitu negatif dan positif.

c. Content.

Adalah isi informasi berkaitan dengan produk dan jasa pada E-Commerce.

\section{PERILAKU KONSUMTIF}

Menurut Sumartono dalam Sofia Miranda perilaku konsumtif merupakan tindakan seseorang membeli suatu barang tanpa adanya pertimbangan yang masuk akal dimana seseorang tersebut dalam membeli sesuatu barangtidak didasarkan pada faktor kebutuhan. ${ }^{13}$ Perilaku

\footnotetext{
${ }^{13}$ Sofia Miranda, "Pengaruh Instagram Sebagai Media Online Shopping Fashion Terhadap Perilaku Konsumtif Mahasiswi Fakultas Ilmu Sosial
} 
konsumtif merupakan perilaku mengkonsumsi barang dan jasa yang mahal dengan intensitas yang terus meningkat demi mendapatkan sesuatu yang lebih baru, lebih bagus dan lebih banyak serta melebihi kebutuhan yang sebenarnya untuk menunjukkan status social, prestige, kekayaan dan keistimewaan, juga untuk mendapatkan kepuasan atas kepemilikan. ${ }^{14}$

Lina dan Rasyid mengukur Perilaku Konsumtif dengan indikator: ${ }^{15}$

\section{Impulsive Buying}

keputusan membeli produk atau jasa yang tidak direncanakan. Atau keputusan membeli terjadi secara tibatiba dan seketika sebelum melakukan pembelian.

\section{Non Rational Buying}

Non rational buying adalah perilaku konsumen yang mudah terbujuk oleh iming-iming diskon atau marketing dari suatu produk tanpa mengedepankan aspek kebutuhan atau kepentingan.

Dan IImu Politik Universitas Riau," JOM FISIP Vol. 4 No. 1 - Februari 2017 4, no. 2 (2017): 1-13.

${ }^{14}$ Eva Suminar dan Tatik Meiyuntari, “Konsep Diri, Konformitas Dan Perilaku Konsumtif Pada Remaja," Persona, Jurnal Psikologi Indonesia Mei 2015, Vol. 4, No. 02, hal 145 - 152 4, no. 02 (2015). h. 147.

${ }^{15}$ L. dan. (1997). Perilaku Konsumtif Berdasar Locus of Control pada Remaja. Psikologika. Rosyid, Lina danRosyid, "Perilaku Konsumtif Berdasar Locus of Control Pada Remaja," Psikologika (1997): 5-13.

\section{Wasteful Buying}

Perilaku konsumen dalam membeli barang dan jasa yang tidak berguna ataumengkonsumsi lebih dari dari kebutuhan atau dengan kata lain adalah pemborosan dalam berbelanja.

\section{METODOLOGI}

Penelitian ini merupakan penelitian kuantitatif menggunakan metode regresi sederhana, dengan tujuan untuk mengetahui pengaruh dan seberapa besar kontribusi e-wom terhadap perilaku konsumtif mahasiswa. Teknik sampling pada penelitian ini adalah nonprobability sampling yang artinya tidak semua unit populasi memiliki kesempatan untuk dijadikan sampel penelitian hal ini karena sifat populasi itu sendiri yang heterogen sehingga terdapat diskriminasi tertentu dalam unit-unit populasi. ${ }^{16}$ Pada penelitian ini menggunakan teknik sampling kuota adalah teknik pengambilan sampel dimana jumlah responden yang akan diteliti ditetapkan terlebih dahulu, baru kemudian siapa yang akan dipilih menjadi anggota sampel terserah peneliti. ${ }^{17}$ Adapun jumlah sampel pada penelitian ini sebanyak 30 responden. $^{18}$

\footnotetext{
${ }^{16}$ Burhan Bungin, Metodologi Penelitian Kuantitatif (Jakarta: Jakarta, 2005).

${ }^{17}$ Anwar Sanusi, Metodologi Penelitian Bisnis (Jakarta: Salemba Empat, 2016). h. 95.

${ }^{18}$ Michel Barrow, Statistic for Economics, Accounting and Bussiness (Edinburg: Longman
} 
Teknik pengumpulan data yang dilakukan adalah dengan menggunakan kuesioner yang akan disebarkan kepada beberapa mahasiswa yang dijadikan sampel penelitian.

\section{HASIL DAN PEMBAHASAN}

Penelitian ini dilakukan pada sample 30 orang mahasiswa IAIN Bengkulu dengan karakteristik responden sebagai berikut:

1. Jenis Kelamin

Tabel 1

Jenis Kelamin

\begin{tabular}{|l|l|}
\hline Jenis Kelamin & Jumlah \\
\hline Laki- laki & 9 \\
\hline Perempuan & 21 \\
\hline
\end{tabular}

Berdasarkan tabel di atas dapat diketahui dari 30 0rang responden mahasiswa FEBI IAIN Bengkulu maka jumlah responden laki-laki sebanyak 30\% mahasiswa dan $70 \%$ mahasiswa perempuan. Jumlah Uang Saku

Tabel 2

Jumlah Uang Saku

\begin{tabular}{|l|c|}
\hline $\begin{array}{l}\text { Jumlah Uang Saku } \\
\text { (Rupiah) }\end{array}$ & $\begin{array}{l}\text { Jumlah } \\
\text { (Orang) }\end{array}$ \\
\hline $500.000-1.000 .000$ & 11 \\
\hline
\end{tabular}

\begin{tabular}{|l|c|}
\hline Tempat Tinggal & Jumlah (Orang) \\
\hline Kos & 17 \\
\hline Dengan Orang Tua & 12 \\
\hline Sanak Family & 1 \\
\hline
\end{tabular}

Dari tabel di atas dapat diketahui bahwa 56,6\% mahasiswa yang jadi responden tinggal di kos-kosan. Yang berarti bahwa mahasiswa tersebut mengelola sendiri uang bulanan yang telah diberikan oleh kedua orang tua mereka.

Group and Pearson Education, 2001). h.190-191. Dalam statistika, sampel yang berukuran lebih dari 30 termasuk dalam ukuran besar dan diharapkan dapat menggambarkan karakteristik populasi yang sebenarnya. 
3. Penggunaan Shopee

Tabel 4

Memiliki Akun Shopee

\begin{tabular}{|l|c|}
\hline Memiliki akun Shopee & Jumlah (Orang) \\
\hline Ya & 27 \\
\hline Tidak & 3 \\
\hline
\end{tabular}

$90 \%$ mahasiswa yang menjadi responden adalah mahasiswa yang memiliki aplikasi shopee dan pernah berbelanja melalui aplikasi tersebut.

4. Waktu yang dihabiskan untuk membuka aplikasi belanja online shopee

\section{Tabel 5}

Jangka Waktu penggunaan Shopee

\begin{tabular}{|c|c|}
\hline Lamanya Waktu (Jam) & Jumlah (Orang \\
\hline 8 & 9 \\
\hline 5 & 6 \\
\hline 3 & 6 \\
\hline 1 & 5 \\
\hline$<1$ & 4 \\
\hline
\end{tabular}

Mahasiswa menghabiskan waktu untuk membuka shopee berkisar <1 sampai dengan 8 jam perhari. Sehingga sangat memungkinkan mahasiswa untuk membaca komentar-komentar barang belanja yang terdapat pada aplikasi.
5. Hasil uji regresi sederhana

Coefficients

\begin{tabular}{|c|c|c|c|c|c|}
\hline \multirow[b]{2}{*}{ Model } & \multicolumn{2}{|c|}{$\begin{array}{l}\text { Unstandardized } \\
\text { Coefficients }\end{array}$} & $\begin{array}{l}\text { Standardized } \\
\text { Coefficients }\end{array}$ & \multirow[b]{2}{*}{$\mathrm{t}$} & \multirow[b]{2}{*}{ Sig. } \\
\hline & B & $\begin{array}{l}\text { Std. } \\
\text { Error }\end{array}$ & Beta & & \\
\hline 1 (Constant) & 7.952 & 2.956 & & 2.690 & .012 \\
\hline ewom & 649 & .142 & .654 & 4.571 & .000 \\
\hline
\end{tabular}

konsumtif

Dari tabel di atas dapat diketahui bahwa E-wom berpengaruh terhadap perilaku konsumtif. Hal ini ditunjukkan dengan nilai $0,000<0,005$. Nilai koefisien regresi sebesar 0,649 . Hal ini menunjukkan bahwa e-wom berpengaruh positif terhadap perilaku konsumtif, yaitu semakin sering mahasiswa membaca ewom pada aplikasi belanja Shopee maka akan semakin tinggi tingkat perilaku konsumtifnya.

6. Hasil uji regresi untuk kontribusi

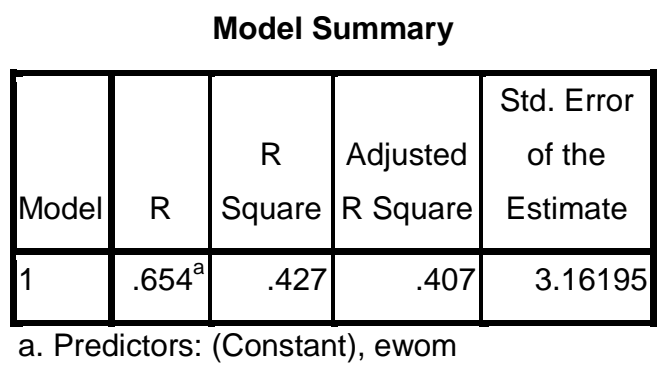

Pada tabel di atas dapat diketahui bahwa e-wom berkontribusi sebesar $42,7 \%$ terhadap perilaku konsumtif. 
Membaca ulasan atau e-wom sebelum berbelanja memberikan pengaruh positif terhadap keputusan berbelanja. Namun membaca e-Wom juga dapat menimbulkan perilaku negatif yaitu perilaku konsumtif, hal ini dikarenakan terjadinya impulse buying pada saat melihat platform berbelanja. Islam memperbolehkan adanya tingkat (gradasi) ekonomi dalam masyarakat, dan Islam juga mengakui adanya kesamaan dalam kebutuhan pokok. Ibnu Hazm menjelaskan kebutuhan pokok hidup bagi seseorang adalah: ${ }^{19}$

1. Harus memiliki cukup makan untuk menjaga tubuhnya agar tetap sehat dan kuat.

2. Harus mempunyai pakaian yang layak untuk berlindung dari kedinginan dan kepanasan.

3. Harus mempunyai tempat tinggal yang baik untuk melindungi dirinya dari iklim yang kurang dan untuk bisa hidup mandiri.

Jika konsumsi dilakukan melebihi kebtuhan pokok maka dapat dikategorikan konsumsi berlebih-lebihan atau perilaku konsumtif. Konsumsi berlebih-lebihan merupakan ciri khas masyarakat yang tidak mengenal tuhan, dikutuk dalam Islam dan disebut dengan istilah israf

\footnotetext{
${ }^{19}$ Afzalur Rahman, Economic Doctrines of Islam Jilid 2 (Jakarta: Dana Bhakti Wakaf, 1995). h. 134
}

(pemborosan) atau (menghambur-untuk menuju tujuan-tujuan yang terlarang seperti penyuapan, hal-hal yang melanggar hukum atau dengan cara yang tanpa aturan. ${ }^{20}$

\section{E. PENUTUP}

Berdasarkan uraian di atas dapat disimpulkan bahwa:

1. E-WOM berpengaruh positif terhadap perilaku konsumtif mahasiswa

2. E-wom berkontribusi sebesar $42,7 \%$ terhadap perilaku konsumtif mahasiswa.

Dari kesimpulan tersebut, saran yang diberikan pada penelitian ini

1. E-WOM berpengaruh positif terhadap perilaku konsumtif sehingga disarankan untuk membuka aplikasi platform belanja online hanya jika terdapat barang yang dibutuhkan untuk dibeli.

2. Ewom berkontribusi sebesar $42,7 \%$ terhadap perilaku konsuumtif sedangkan $57,3 \%$ dipengaruhi oleh faktor lain yang tidak diteliti pada penelitian ini sehingga penulis lainnya dapat melakukan penelitian berikutnya

\footnotetext{
${ }^{20}$ Monzer Kahf, The Islamic Economis: Analytical Study of the Functioning of the Islamic Economic System (Plainfield, Indiana: The Muslim Students' Association of the United States and Canada, 1979). H.24
} 
dengan menggunakan variabel yang berbeda.

\section{F. PUSTAKA RUJUKAN}

Afzalur Rahman. Economic Doctrines of Islam Jilid 2. Jakarta: Dana Bhakti Wakaf, 1995.

Azzura, Siti Nur. "Survei: Indonesia Jadi Surga Belanja Online Terbesar SeAsia Tenggara.” Last modified 2017. Accessed February 8, 2018. https://www.merdeka.com/uang/surv ei-indonesia-jadi-surga-belanjaonline-terbesar-se-asiatenggara.html.

Bungin, Burhan. Metodologi Penelitian Kuantitatif. Jakarta: Jakarta, 2005.

Eva Suminar dan Tatik Meiyuntari. "Konsep Diri, Konformitas Dan Perilaku Konsumtif Pada Remaja." Persona, Jurnal Psikologi Indonesia Mei 2015, Vol. 4, No. 02, hal 145 1524 , no. 02 (2015).

Fuel, Fan \&. "No Online Customer Reviews Means BIG Problems in 2017.” Last modified 2017. Accessed $\begin{array}{lll}\text { February } & \text { 8, }\end{array}$ https://fanandfuel.com/no-onlinecustomer-reviews-means-bigproblems-2017/.

Hifziati, Laila. "Pembentukan Kultur Konsumtif Melalui E-Wom Kuliner Di Instagram.” Komunikator 9 No. 2
De (2017).

Kruh, Willy. "The Truth about Online Consumers." KPMG International (2017): 1-40.

Kusumaningrum, Ayu, Bagus Wicaksono, and Rahmah Saniatuzzulfa. "Hubungan Electronic Word of Mouth Dan Hedonic Shopping Motivation Dengan Perilaku Konsumtif Produk Make Up Pada Mahasiswi Relationship between Electronic Word of Mouth and Hedonic Shopping Motivation with Consumable Behavior of Make Up Products for Studen" 14 (2018).

Lestari, Mustiana. "E-Commerce Ini Paling Banyak Dicari Netizen Di Google," 2018. https://inet.detik.com/business/d3847985/e-commerce-ini-palingbanyak-dicari-netizen-di-google.

Librianty, Andina. "Ini 10 Toko Online Terbaik Di Indonesia." Last modified 2017. Accessed February 8, 2018. https://www.liputan6.com/tekno/read /3068210/ini-10-toko-online-terbaikdi-indonesia.

Meuthia. "Efektifitas Electronic Word of Mouth (e-WOM) Melalui Media Sosial." Teknosi Vol. 03, no. 01 (2017): 101-108.

Michel Barrow. Statistic for Economics, Accounting and Bussiness. Edinburg: 
Longman Group and Pearson Education, 2001.

Miranda, Sofia. "PENGARUH

INSTAGRAM SEBAGAI MEDIA

ONLINE SHOPPING FASHION

TERHADAP

PERILAKU

KONSUMTIF

MAHASISWI

FAKULTAS ILMU SOSIAL DAN

ILMU POLITIK UNIVERSITAS

RIAU." JOM FISIP Vol. 4 No. 1 -

Februari 2017 4, no. 2 (2017): 1-13.

Monzer Kahf. The Islamic Economis:

Analytical Study of the Functioning

of the Islamic Economic System.

Plainfield, Indiana: The Muslim

Students' Association of the United

States and Canada, 1979.

Rabben, Ingrid, Vilde Instanes Larsen,

Master Thesis, and Brand

Management. "Electronic Word-of-

Mouth and Consumers ' Intention to

Reviews"(2017).

Rosyid, Lina danRosyid, L. dan. (1997).

Perilaku Konsumtif Berdasar Locus

of Control pada Remaja. Psikologika.

"Perilaku Konsumtif Berdasar Locus

of Control Pada Remaja."

Psikologika (1997): 5-13.

Sanusi, Anwar. Metodologi Penelitian

Bisnis. Jakarta: Salemba Empat, 2016.

Sari, Fungki dan Pangesti, Edriana.

"Pengaruh Electronic Word Of
Mouth (e-WOM) Terhadap Minat Berkunjung Dan Keputusan Berkunjung." Jurnal Administrasi Bisnis Vol. 54, no. 1 (2018): 189196.

“BULETINAPJIIEDISI22Maret2018.Pdf, $"$ n.d.

"Laporan Kuartal I 2018 Industri ECommerce Indonesia.” Last modified 2018. Accessed April 20, 2018. https://iprice.co.id/trend/insights/lapo ran-kuartal-i-2018-industri-ecommerce-indonesia/.

"Persaingan E-Commerce Indonesia Di 2017, Siapa Terpopuler?" 31 Desember. Last modified 2017. Accessed February 8, 2018. https://inet.detik.com/cyberlife/d3793019/persaingan-e-commerceindonesia-di-2017-siapa-terpopuler. 